\title{
Razem dla spójnego miasta. Zjawisko synergii na przykładzie współpracy Politechniki Lubelskiej i Urzędu Miasta Zaklikowa
}

\section{Together for a cohesive city. The synergy phenomenon on the example of the cooperation between the Lublin University of Technology and Zaklików City Office}

\section{Streszczenie}

Trzecie Warsztaty Studenckie z cyklu "Synergia w Architekturze” odbyły się w Zaklikowie w lipcu 2016 roku. Cykl ten jest organizowany od 2015 roku przez Politechnikę Lubelską we współpracy z władzami samorządowymi ośrodków-gospodarzy. Warsztaty zaowocowały pracami studialnymi i projektami oraz rozpoczęciem dialogu na temat przyszłości tego miasta - pomiędzy mieszkańcami, władzami i przedstawicielami uczelni. To pierwszy etap synergicznej współpracy, której celem jest spójny i nowoczesny Zaklików.

Słowa kluczowe: miasto, synergia, warsztaty studenckie, Zaklików

\section{Abstract}

The third Student Workshops from the series "Synergy in Architecture" took place in Zaklików in July 2016. This series is being organized since 2015 by the Lublin University of Technology in cooperation with the local government of the hosts. The results of the workshops were studies, projects and a dialogue about the future of the city - between inhabitans, government and representatives of the University. This is the first stage of synergistic cooperation, which aims at a coherent and modern Zaklików.

Keywords: city, synergy, student workshops, Zaklików 


\section{WSTĘP}

Niniejszy artykuł poświęcony jest niewielkiemu miastu Zaklików, położonemu w północno-zachodniej części województwa podkarpackiego. To niewielki, kilkutysięczny ośrodek, który stoi u progu zmian, które mogą odmienić jego wizerunek, podnieść atrakcyjność i przyciągnąć do niego nowych mieszkańców. W 2016 roku Samodzielna Pracownia Architektoniczna Wydziału Budownictwa i Architektury Politechniki Lubelskiej nawiązała współpracę z Gminą Zaklików w celu przeprowadzenia Warsztatów Studenckich z możliwością wdrożenia rozwiązań projektowych i dalszych aktywności. Warsztaty były także okazją do wymiany poglądów oraz dyskusji na temat przyszłości miejscowości, w tym do porównania wizji i potrzeb mieszkańców, władz samorządowych i przedstawicieli Uczelni: nauczycieli akademickich i studentów.

\section{KILKA SŁÓW O ZAKLIKOWIE}

Zaklików otrzymał prawa miejskie magdeburskie 9 kwietnia 1565 roku, nadaniem króla Zygmunta Augusta. Miasto lokowano na „surowym korzeniu” - na gruntach wsi Zdziechowice Drugie. Założycielem i pierwszym właścicielem miasta był Stanisław Zaklika z Czyżowa herbu Topór, od którego nazwiska miasto wzięło swoją nazwę. Miasto pozostawało w rękach prywatnych aż do rozbiorów; właścicielami Zaklikowa byli m.in. Gniewoszowie, Załuscy i Małachowscy.

Około roku 1580 wybudowano drewniany kościół św. Anny, działający jako filia parafii w sąsiednich Zdziechowicach. Przy kościele w 1581 r. wybudowano szpital (przytułek) i założono szkołę parafialną. Niedługo później właściciel miasta, Marcin Gniewosz, przekształcił kościół na zbór kalwiński, jednak już w 1594 roku obiekt spłonął. W 1608 roku erygowano nową, rzymskokatolicką parafię pw. Trójcy Przenajświętszej - już w Zaklikowie, w nowym, murowanym kościele. Była to fundacja Anny Gniewoszowej, która po śmierci męża nawróciła się na katolicyzm.

W kolejnych wiekach miasto stopniowo rozwijało się, pozostając jednak niewielkim ośrodkiem. Znajdowało się w województwie lubelskim i to z Lublinem miało najmocniejsze związki.

Koniec XVIII i początek XIX wieku były dla Zaklikowa wyjątkowo burzliwe z powodu częstych zmian granic. Po upadku Polski w 1795 roku miasto znalazło się w zaborze austriackim, jednak już w 1809 roku, po klęsce Austrii w wojnie z napoleońską Francją, Zaklików wszedł w skład Księstwa Warszawskiego, a raptem sześć lat później (1815), po upadku Napoleona, znalazł się w granicach Królestwa Kongresowego - pod panowaniem rosyjskim. Granica pomiędzy cesarstwami znajdowała się nieopodal Zaklikowa - do dziś na pamiątkę na obrzeżach gminy stoi słup graniczny. W 1869 roku, w ramach represji po upadku powstania styczniowego, Zaklików utracił prawa miejskie. Odzyskał je dopiero w XXI wieku - w roku 2014 roku ponownie stał się miastem w świetle prawa. 
Podczas I wojny światowej, w roku 1915, wybudowano linię kolejową, która połączyła Lublin z zaborem austriackim, a Zaklików ze stolicą regionu i dalej - z krajem i Europą.

Na początku XX wieku Zaklików liczył ok. 4 tysięcy mieszkańców, z czego znaczną część stanowili Żydzi. Kres ich spokojnej egzystencji przyniosła tragedia Holocaustu - większość zaklikowskich Żydów zginęła w obozie zagłady w Bełżcu. Wymownym śladem tej społeczności jest żydowski cmentarz z kilkoma zachowanymi macewami.

Okres PRL to odbudowa miasta po wojnie - szczególnie dotkliwa dla Zaklikowa była eksterminacja ludności żydowskiej, zniszczenia materialne dotyczyły go w mniejszym stopniu - i jego stopniowy rozwój. Powstało wówczas kilka zakładów przemysłowych i budynków użyteczności publicznej.

Obecnie Zaklików liczy około 3 tysięcy mieszkańców i jest najdalej na północ wysuniętym miastem województwa podkarpackiego. Działa w nim kilka zakładów produkcyjnych i usługowych, m.in. Zakład Energetyczny, Zakład Drzewny „Rejon Las”, HSW S.A. - Fabryka Elementów Złączonych „Fasctec” (filia Huty Stalowa Wola). Jest siedzibą szkoły podstawowej, gimnazjum i liceum ogólnokształcącego, tworzących zespół szkół. W mieście działa również Gminny Ośrodek Kultury, Muzeum Ziemi Zaklikowskiej, świetlica i biblioteka, jednak zaplecze kulturalne jest ubogie i wymaga zdecydowanych zmian i poszerzenia oferty.

Mimo utraty praw miejskich Zaklików zachował miejski układ urbanistyczny, wpisany 2 sierpnia 1982 roku do rejestru zabytków pod numerem rej. 232/A. Najcenniejszymi zabytkami Zaklikowa są kościoły św. Anny (modrzewiowa kaplica cmentarna z końca XVI wieku) i Trójcy Przenajświętszej (parafialna, barokowa świątynia z początku XVII wieku).

\section{WARSZTATY STUDENCKIE}

Warsztaty Studenckie z cyklu „Synergia w Architekturze”, organizowane są od roku 2015 przez Samodzielną Pracownię Architektoniczną Wydziału Budownictwa i Architektury Politechniki Lubelskiej, Fundację Rozwoju Politechniki Lubelskiej oraz Fundację na Dużą Skalę (Poznań). Pomysłodawcą Warsztatów jest dr hab. inż. arch. Jan Wrana, prof. nadzw. PL, który zainspirowany został przez prof. Zbigniewa Bacia, organizatora wrocławskich warsztatów HABITATY, poświęconych środowisku mieszkaniowemu.

Warsztaty „Synergia w architekturze” skupiają się na zagadnieniach architektury integrującej przestrzeń w strukturach urbanistycznych miast. Podejmują one aktualne problemy współczesnych miast: utratę spójności struktury przestrzennej, konieczność rewitalizacji przestrzeni oraz jej „integracji” - scalania poprzez wprowadzenie nowych form i obiektów.

Poprzednie edycje warsztatów podjęły temat rewitalizacji rejonu Rotundy w Zamościu - miejsca ważnego formalnie i przestrzennie, obecnie Muzeum Martyrologii oraz centrum wsi Żółkiewka, gdzie m.in. zaproponowano ścieżkę historyczną, upamiętniającą chwałę polskiego oręża oraz bohaterów Ziemi Chełmskiej: Stanisława Żółkiewskiego, Jana Zamojskiego i Jana III Sobieskiego. 


\section{WARSZTATY W ZAKLIKOWIE}

Trzecie warsztaty studenckie z cyklu „Synergia w Architekturze” odbyły się w dniach 3-9 lipca 2016 roku w Zaklikowie i Lublinie. W ramach warsztatów opracowywano dwa tematy projektowe: „Rewitalizację domu kultury” oraz „Przekształcenia przestrzeni publicznej - rynku".

Warsztaty zorganizowano we współpracy nauczycieli akademickich z Samodzielnej Pracowni Architektonicznej WBiA PL z Urzędem Miasta i Gminy Zaklików. Opiekunem naukowym był prof. Jan Wrana, zaś opiekunami grup studenckich: dr inż. arch. Kamila Boguszewska, mgr inż. arch. Olga Skoczylas, mgr inż. arch. Karol Krupa i mgr inż. arch. Piotr Gleń. W warsztatach wzięło udział 26 studentów kierunku Architektura ${ }^{1}$ (il. 1).

Warsztaty podjęły tematy aktualne i ważne dla mieszkańców. Zarówno kwestia modernizacji obiektu kultury, jak i przestrzeni publicznej (rynku), wymagały konstruktywnej dyskusji i podjęcia działań. Ich zdanie i opinie były ważną wytyczną projektową, dlatego zespół pierwszy raz spotkał się z mieszkańcami miasta jeszcze przed warsztatami - miało to miejsce podczas wizji lokalnej 24 czerwca 2016. W czasie spotkania pozyskano listę oczekiwanych przez mieszkańców rozwiązań koncepcyjnych, zarówno dla rewitalizacji domu kultury jak i dla przekształceń przestrzeni publicznej - rynku.

Podczas warsztatów studenci podzieleni na grupy opracowywali-pod okiem opiekunów grup - wariantowe propozycje i koncepcje dotyczące dwóch wiodących tematów. Brali pod uwagę zarówno potrzeby mieszkańców, jak i kontekst miejsca, jego historię i sąsiedztwo oraz współczesne trendy w architekturze. Efektem prac studentów był wachlarz interesujących rozwiązań, który został przedstawiony mieszkańcom i władzom podczas kolejnego spotkania w dniu 24 listopada 2016. Zaprezentowano na nim atrakcyjne propozycje generalnych zmian, poddając je publicznej dyskusji oraz uzyskując pozytywne oceny mieszkańców dla zaprezentowanych rozwiązań.

\subsection{GMINNY OŚRODEK KULTURY}

Obecny Gminny Ośrodek Kultury jest niewielkim budynkiem zlokalizowanym w centrum miejscowości, powstałym w okresie PRL. Wizualnie prezentuje styl charakterystyczny dla budynków z tego okresu: prostą bryłę z regularnymi przeszkleniami w formie prostokątnych okien, z mocnym akcentem w postaci trzech par czerwonych drzwi garażowych, gdyż oprócz funkcji kulturalnych obiekt pełni funkcję remizy. Dysponuje on salą widowiskową oraz niezbędnym, podstawowym zapleczem, jest jednak niewystarczający wobec potrzeb mieszkańców. Pod kątem rodzaju i ilości zajęć GOK działa bowiem bardzo aktywnie, prowadząc zarówno dla młodzieży, jak i dorosłych: klub poezji, kółko plastyczne, naukę gry na instrumentach muzycznych, chór męski, klub seniora i koło ZBoWiD. Efekty tych działań przedstawiane są w formie wystaw, koncertów, festynów rekreacyjno-kulturalnych oraz uczestnictwa 
w okolicznościowych spotkaniach rocznicowych lub uroczystościach z okazji świąt państwowych. Wszystkie te aktywności wymagają odpowiedniego, komfortowego zaplecza, funkcjonalnego i bezpiecznego. Wskazane jest również unowocześnienie elewacji, która winna być otwarta na potencjalnego użytkownika i „zapraszać” do wnętrza.

Współczesne ośrodki kultury wyraźnie różnią się od „domów kultury” działających w okresie PRL. Choć spora część z nich powstała właśnie w tym okresie i zajmuje wciąż te same obiekty, to by prężnie działać musiała przejść modernizację - dotyczącą zarówno samego obiektu, jak i jego oferty. Nowoczesny ośrodek musi „iść z duchem czasu”, jego oferta zaś być aktualna i atrakcyjna dla dzisiejszego użytkownika, skierowana nie tylko do dzieci. Musi wykraczać poza utarte ramy i schematy, proponować coś odkrywczego, nietypowego, trudnego do indywidualnej realizacji. Do realizacji takiego programu konieczna jest wykształcona kadra i odpowiedni sprzęt oraz zaplecze. Ośrodki kultury to nowoczesne firmy, świadczące usługi kulturalne². Wymiernym efektem współpracy Politechniki i UM Zaklikowa, rozpoczętej warsztatami, było opracowanie przez Samodzielną Pracownię Architektoniczną projektu docelowej modernizacji Ośrodka. W opracowaniu uwzględniono zarówno potrzeby mieszkańców, jak i aktualne standardy obowiązujące dla obiektów kultury oraz trendy w architekturze. Pierwszy etap realizacji przewidziany jest na drugą połowę 2017 roku. Zmodernizowany obiekt będzie dysponował nowoczesną salą widowiskową, komfortowymi biurami, biblioteką i niezbędnym zapleczem. Przewidziano również garaż i zaplecze dla Straży Pożarnej. Zmianie ulegnie również bryła budynku - zyska on interesującą szatę zewnętrzną, jednocześnie atrakcyjną i przyciągającą uwagę oraz dostosowaną do otoczenia.

\subsection{RYNEK}

Również przestrzeń publiczna miasta wymaga zmian i unowocześnienia. Zaklików, mimo utraty praw miejskich na prawie 150 lat, zachował miejską strukturę urbanistyczną. Od 2014 roku z powrotem jest miastem i rozpoczyna walkę o spójną strukturę przestrzenną. Rynek - oficjalnie plac Sienkiewicza - który winien być wizytówką i salonem Zaklikowa, jest odremontowany i zadbany, lecz nie jest „sercem” miasta. Konieczne jest przekształcenie tej przestrzeni i jej ożywienie.

Na przestrzeni ostatnich lat rynki wielu miast zmieniają swoje oblicza. Przestają być węzłami komunikacyjnymi, do której to roli często zostały sprowadzone w drugiej połowie XX wieku. Przeprowadza się wielowątkową renowację: wprowadza się uspokojenie ruchu, umieszcza interesującą i funkcjonalną małą architekturę, modernizuje płytę rynku, porządkuje zieleń. Na rynki powraca handel: w wyważonej i eleganckiej formie, dalekiej od targowych jatek. Celem tych działań jest kompleksowa rewitalizacja rynków, czyli przywrócenie ich do życia - stworzenie z nich miejskich salonów, miejsca rekreacji i spotkań mieszkańców. Godnymi naśladowania przykładami zrewitalizowanych rynków są główne place w Skawinie i Gorlicach. 
Wprowadzenie tego typu zmian winno nastąpić również w Zaklikowie. Podczas warsztatów opracowana koncepcję modernizacji rynku (il. 3), której charakterystycznym elementami są atrakcyjnie zaprojektowana zieleń - zarówno wysoka, jak i niższa - oraz ciekawa mała architektura. Tak ukształtowany plac może stać się wizytówką i symbolem miasta, a także miejscem, gdzie mieszkańcy chętnie będą spędzali wolny czas.

\section{ZJAWISKO SYNERGII}

Synergia (z greckiego ouvepүía - współpraca) to pojęcie ponadsumatywności („wartość dodana") wprowadzone przez amerykańskiego konstruktora i architekta R.B. Fullera. Ze zjawiskiem tym mamy do czynienia wówczas, gdy suma składników („suma synergiczna”), ma większą wartość niż każdy z tych składników z osobna (suma arytmetyczna). Na sumę synergiczną składa się, oprócz arytmetycznej wartości czynników, nieuchwytna wartość dodana. Matematycznie można to zapisać równaniem $2+2=5$.

Pojawienie się synergii to wynik efektywnej współpracy. Współdziałanie kilku elementów - ludzi, zjawisk, metod - przełożyć się może na osiągnięcie efektu bardziej doniosłego niż działanie tych elementów osobno, bez korelacji między nimi.

Z synergią spotykamy się między innymi w medycynie, gdy zastosowanie dwóch lub więcej leków razem daje lepsze rezultaty niż każdy z leków osobno. W architekturze przykładem synergii jest genius loci (duch miejsca).

\section{UCZELNIE WYŻSZE A ROZWÓJ REGIONALNY}

Współczesne uczelnie to nie tylko miejsce kształcenia kolejnych pokoleń studentów i teoretycznych rozważań. To wielofunkcyjne ogniska wiedzy o szerokim zasięgu oddziaływania, współpracujące z jednostkami samorządowymi i przemysłem, wdrażające patenty i innowacje, odkrywające nowe rozwiązania, kształtujące miasto i środowisko.

Obecnie rola uczelni najczęściej rozpatrywana jest na czterech płaszczyznach, jako jednostki ekonomicznej, producenta wiedzy, instytucji kształcącej kapitał ludzki oraz instytucji będącej „aktorem regionalnym”3.

Jako jednostka ekonomiczna szkoły wyższe są potężnym pracodawcą (zarówno dla nauczycieli akademickich, jak i pracowników niezwiązanych z nauką) i inwestorem (budowa i modernizacja obiektów, zakup sprzętu). Uczelnia to swoiste „przedsiębiorstwo naukowo-edukacyjne”, nierzadko największe w okolicy, zatrudniające pracowników, „kupujące” produkty i usługi od lokalnych firm, „sprzedające” wiedzę studentom, instytucjom i przedsiębiorcom.

Uniwersytety i politechniki są najważniejszymi w regionie „producentami wiedzy” zarówno teoretycznej (badania podstawowe), jak i stosowanej praktycznie (aplikowanej 
i wdrażanej). To najbardziej tradycyjna gałąź działalności uczelni. Z teoretyczną wiedzą akademicką wiąże się jej praktyczna, stosowana strona, czyli komercjalizacja: powstawanie i wdrażanie innowacji technologicznych oraz tworzenie nowych produktów i procesów. Ma to miejsce zwłaszcza w przypadku umów zawartych z firmami przemysłowymi, budowlanym i farmaceutycznymi. Uczelnie kształcą także wysoko wykwalifikowanych specjalistów, zwiększających kapitał ludzki regionu. Z ich murów wychodzą corocznie nowi absolwenci wykształceni młodzi ludzie, którzy są zaznajomieni z najnowszą wiedzą i technologami oraz sposobem ich stosowania. Istnieje spore prawdopodobieństwo, iż zdecydują się oni zostać w mieście studiowania lub w najbliższej okolicy. Na kapitał ludzki składa się także kadra naukowa uczelni, wciąż podnosząca swoje kwalifikacje i umiejętności.

Pojęcie "aktorów regionalnych" wiąże się z oddziaływaniem uczelni na region. Najkorzystniejszy wpływ obserwujemy wówczas, gdy angażuje się ona w jego społeczny i ekonomiczny rozwój w wielu wymiarach równocześnie, nie ograniczając swojego zaangażowania tylko do relacji z firmami ${ }^{4}$.

\section{SYNERGIA W ZAKLIKOWIE}

W Zaklikowie zjawisko synergii może wystąpić przy podjęciu współpracy środowisk akademickich i władz miasta, wspartych dyskusją z mieszkańcami i zainteresowaniem inwestorów. Poszczególne elementy wpływają na siebie nawzajem, napędzając to pozytywne „synergiczne koło".

Wiedza i doświadczenie nauczycieli akademickich, dotyczące zarówno metodologii projektowania, jak i znajomości najnowszych trendów w architekturze, zasad planowania przestrzennego oraz socjologii architektury, stanowi odpowiednie przygotowanie merytoryczne do podjęcia dyskusji o funkcjonalno-przestrzennych zmianach w Zaklikowie. Świeże spojrzenie i kreatywność studentów przekładają się z kolei na oryginalność pomysłów. Współpraca z władzami miasta pozwala na ustalenie długofalowej polityki związanej z rozwojem przestrzennym i funkcjonalnym miasta, zapewnia również lepsze egzekwowanie przepisów i reagowanie w przypadku ewentualnych nieprawidłowości, np. samowoli budowlanych. Dyskusja z mieszkańcami, wsparta ankietami, przełoży się na rozeznanie potrzeb mieszkańców, ustalenia sposobu ich zaspokojenia oraz nadania im kolejności według priorytetu. Realizacja nowych obiektów, zaspokajających pilne potrzeby, wpłynie pozytywnie na poprawę jakości życia w Zaklikowie i wzrost zadowolenia mieszkańców.

Wszystkie te elementy mogą funkcjonować osobno, jednak ich siła oddziaływania będzie wówczas znacznie mniejsza lub wręcz znikoma. Uniwersyteckie dyskusje i studia staną się interesującymi, lecz teoretycznymi rozważaniami; działania władz (strategie, MPZP, plany rewitalizacji) będą wymagały dodatkowego wsparcia merytorycznego i inwestorskiego, by nie pozostać tylko na papierze; postulaty i potrzeby mieszkańców mogą nie mieć siły przebicia 
i nie przełożyć się na konkretne działania, zaś realizacje inwestorów - korzystny przejaw zainteresowania - w skrajnym przypadku mogą przerodzić się w niekorzystny „deweloping”, czyli niekontrolowane inwestycje, generujące lub pogłębiające chaos przestrzenny.

\section{PODSUMOWANIE}

Warsztaty Studenckie „Synergia w architekturze” to pierwszy etap synergicznej współpracy między władzami miasta i środowiskiem akademickim, której celem jest spójne i nowoczesne miasto Zaklików. Warsztaty, oprócz merytorycznej dyskusji na temat przyszłości tego miasta oraz wymiany poglądów i doświadczeń, przyniosły także wymierne efekty. Były to prace projektowo-studialne, opracowane przez studentów architektury pod okiem opiekunów grup, dotyczące modernizacji domu kultury oraz rynku w Zaklikowie.

Zwieńczeniem warsztatowych doświadczeń było opracowanie projektu modernizacji Gminnego Ośrodka Kultury przez Samodzielną Pracownię Architektoniczną, na zlecenie Urzędu Miasta Zaklikowa. Koncepcja ta, uzupełniona o projekty budowlano-branżowe, przekazana została władzom miasta w maju 2017. Rozpoczęcie realizacji ma nastąpić jesienią tego samego roku, a efektem prac będzie nowoczesny, atrakcyjny i funkcjonalny budynek, spełniający oczekiwania i potrzeby mieszkańców.

Współpraca Politechniki Lubelskiej i UM Zaklikowa wpisuje się w ogólnoświatowy trend gospodarki opartej na wiedzy (knowelodge - based economy) w której wiedza rozumiana jest jako zdolność do działania i odgrywa decydującą rolę w stymulowaniu rozwoju gospodarczego i społecznego każdego regionu ${ }^{5}$. Tendencja ta pozwala na merytoryczne planowanie długofalowego rozwoju w oparciu o wiedzę specjalistów oraz analizy i badania (dotyczące m.in. potrzeb mieszkańców, mocnych i słabych cech regionu itd.), a także budowanie marki ośrodka. Wielowątkowa współpraca Politechniki i władz Zaklikowa, wsparta konsultacjami z mieszkańcami, zaowocować może oczekiwanymi inwestycjami, atrakcyjnymi realizacjami i podniesieniem jakości życia w mieście. 


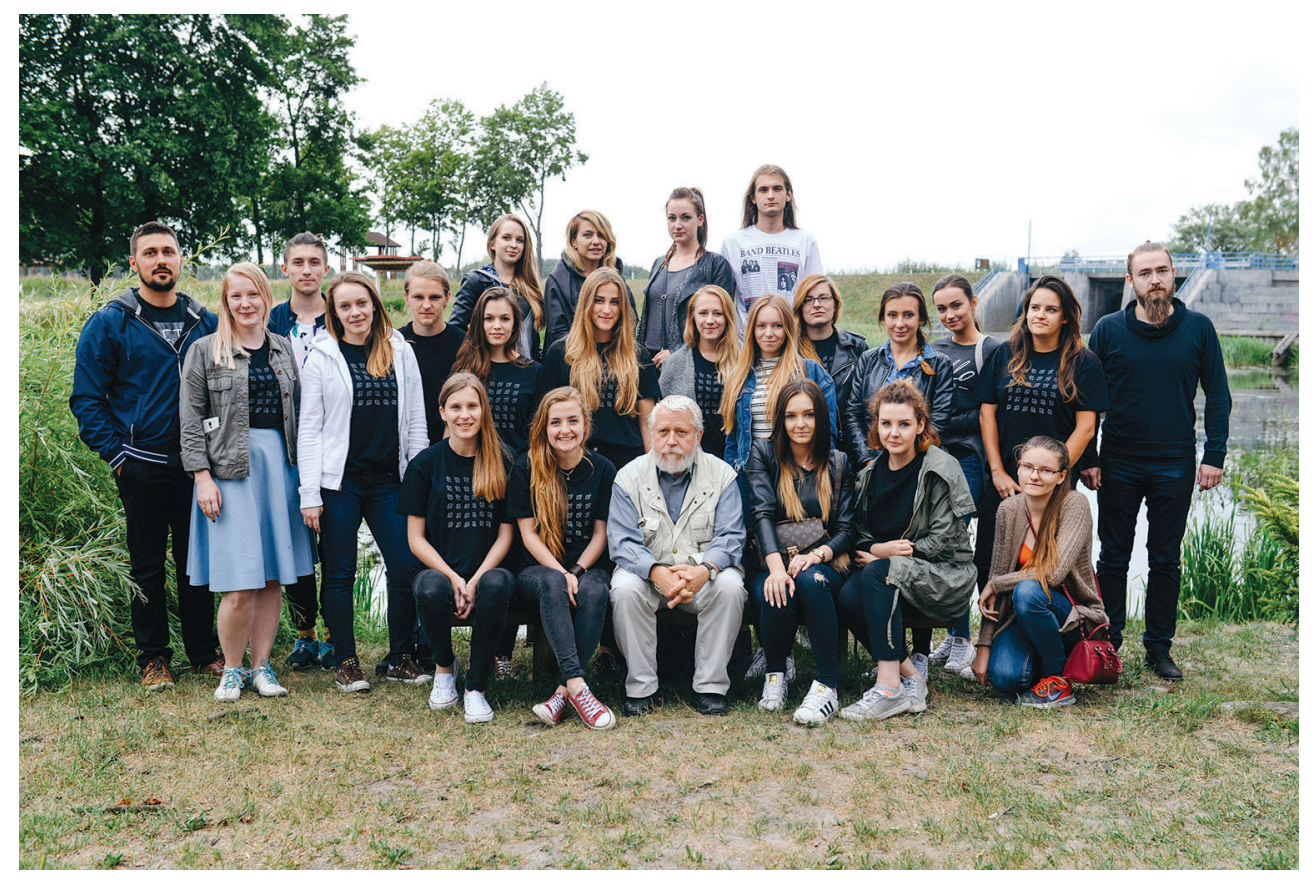

II. 1. Uczestnicy warsztatów oraz prowadzący: dr hab. inż. arch. Jan Wrana, prof. nadzw. PL (opiekun naukowy), arch. arch. Olga Skoczylas, Karol Krupa i Piotr Gleń (opiekuni grup)

III. 1. Workshop participans and tutors: PhD D.Sc. Eng. Arch. Jan Wrana, assoc. Prof. (scientific tutor), architects Olga Skoczylas, Karol Krupa i Piotr Gleń (group carers) 

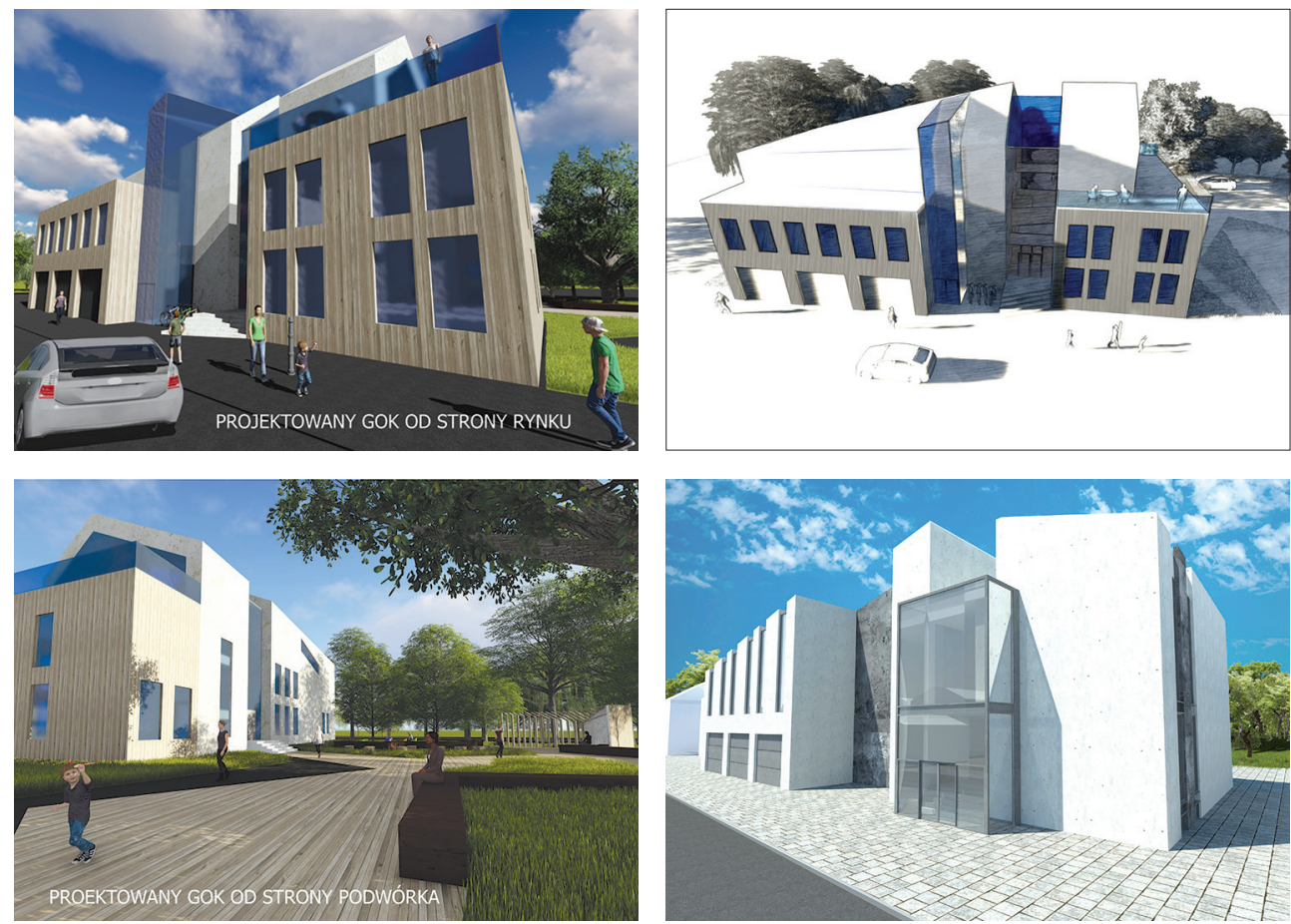

II. 2 a-d. Dwa warianty - propozycje rewitalizacji domu kultury

III. 2 a-d. Two variants - proposals for revitalization of a cultural centre 

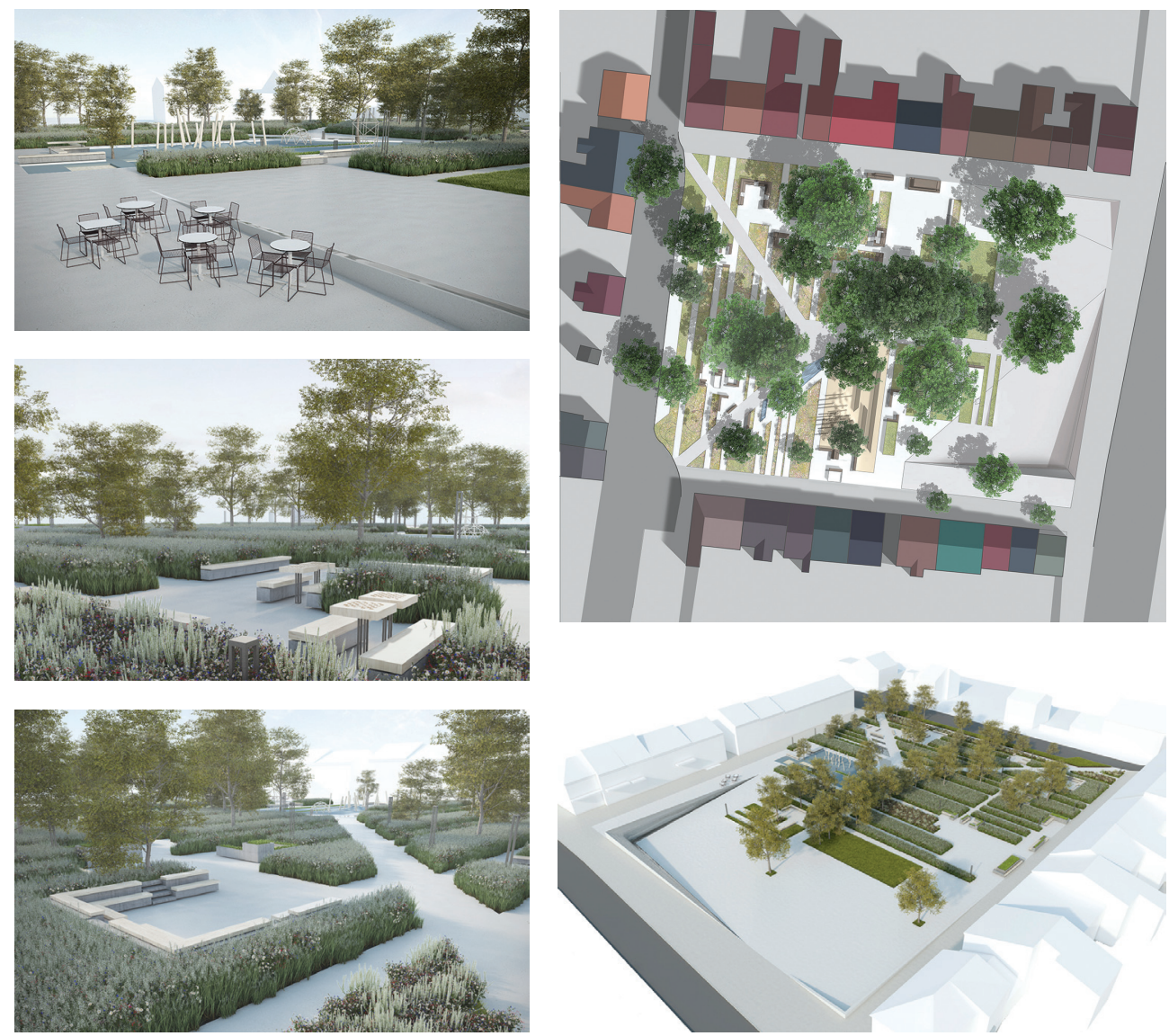

II. 3 a-e. Nowy Rynek w Zaklikowie - propozycja

III. 3. a-e. New Market Square in Zaklików - proposal 

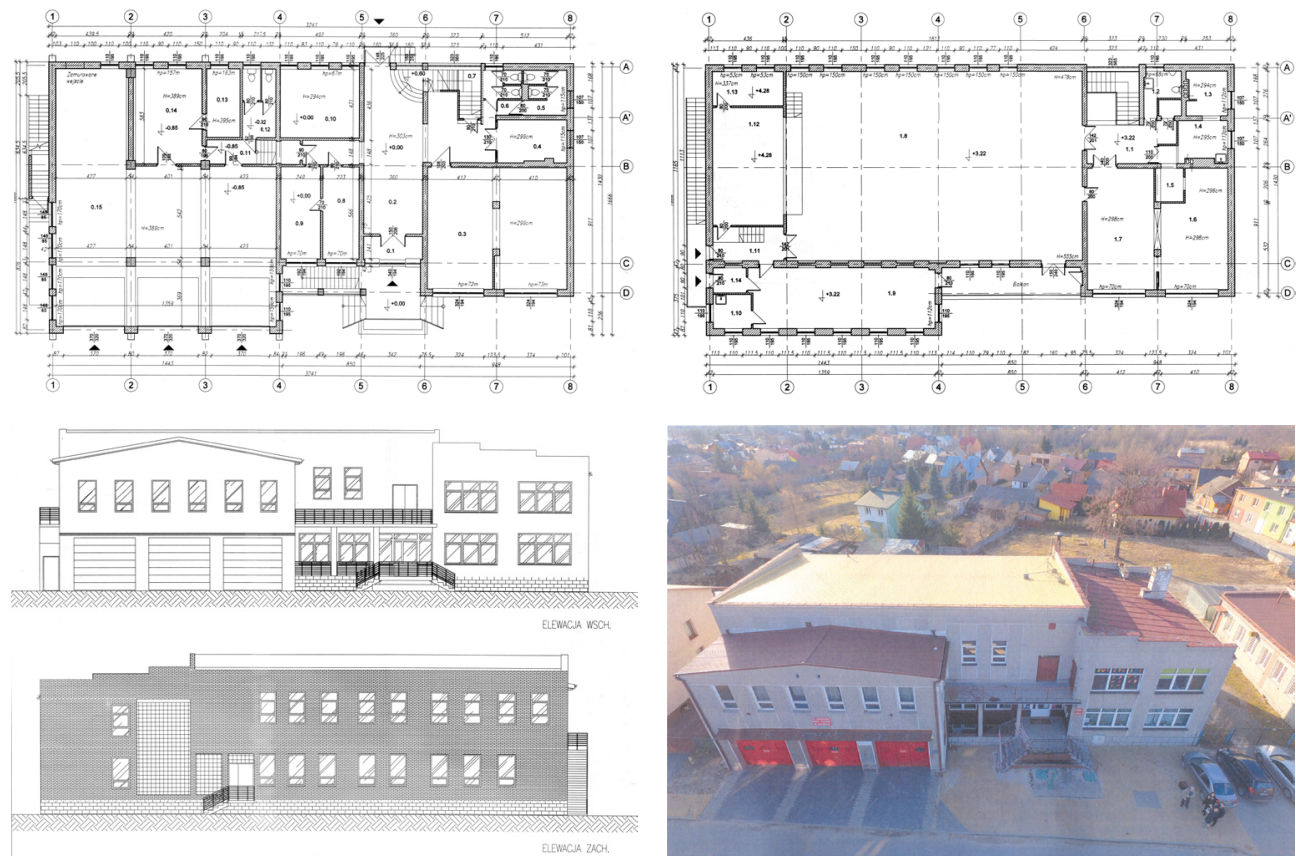

II. 4 a-d. Inwentaryzacja domu kultury: a) rzut parteru (oprac. J. Wrana z zespołem), b) rzut pierwszego piętra (oprac. J. Wrana z zespołem), c) elewacja wschodnia - frontowa i zachodnia - tylna (oprac. J. Wrana z zespołem), d) obiekt w 2017 roku (fot. SPA)

III. 4 a-d. Inventory of a cultural centre: a) ground floor plan (work by J. Wrana and team), b) first floor plan (work by J. Wrana and team), c) east (front) and west (rear) elevations (work by J. Wrana and team), d) building in 2017 


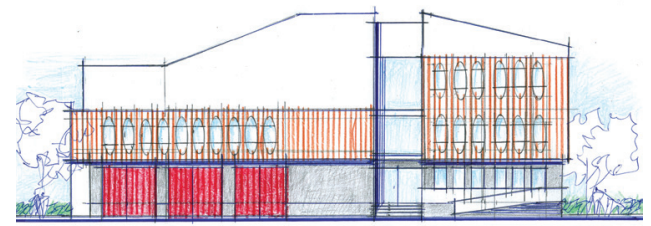

GOK, ZAKLIKOW:
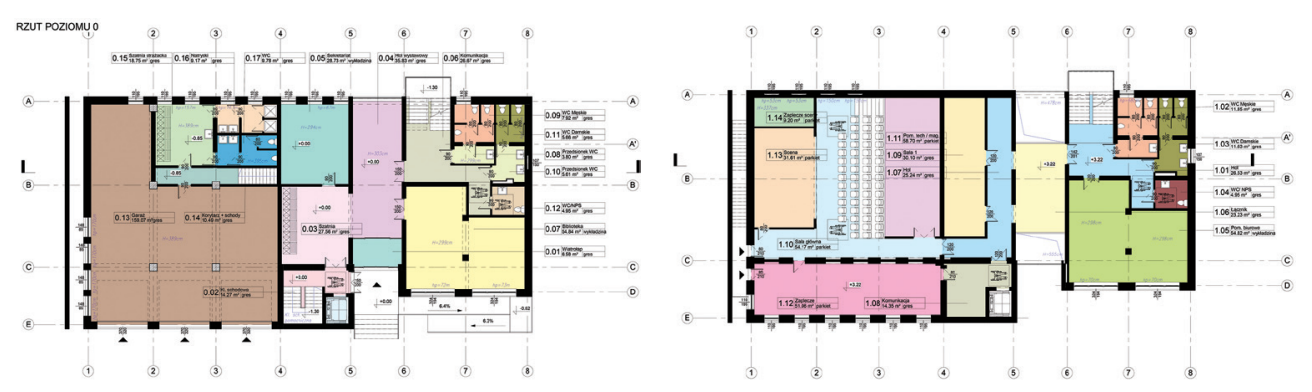

II. 5 a-d. Koncepcja docelowej rewitalizacji domu kultury (z pierwszym etapem realizacji w 2017 roku): a) elewacja wschodnia - frontowa (rys. J. Wrana), b) elewacja zachodnia - tylna (rys. J. Wrana),

c) rzut parteru (oprac. J. Wrana z zespołem); kolor brązowy - garaż, żółty - biblioteka, turkusowy - sekretariat, fioletowy - hol wystawowy, d) rzut pierwszego piętra (oprac. J. Wrana z zespołem); turkusowy - sala główna, jasnopomarańczowy - druga sala, różowy - zaplecze, zielony - biura

III. $5 \mathrm{a}$-d. The concept of the revitalization og the cultural centre (with the first stage of implementation in 2017): a) east (front) elevation (drawing by J. Wrana), b) west (rear) elevation (drawing by J. Wrana), c) ground floor plan (work by J. Wrana and team); brown - garage, yellow library, turquoise - secretary, violet - exhibition hall; d) first floor plan (work by J. Wrana and team); turquoise - main hall, light orange - second hall, pink - technic room, green - offices 


\section{PRZYPISY}

1 Uczestnicy warsztatów: 1. Trójczak Aleksandra, 2. Olszak Magdalena, 3. Pastuszak Klaudia, 4. Pawłowska Katarzyna, 5. Koniarska Patrycja, 6. Miazga Dominika, 7. Tomas Karolina, 8. Więsyk Agnieszka, 9. Mazurek Aleksandra, 10. Tyvonchuk Olena, 11. Mitkowska Ada, 12. Iwaszko Aleksandra, 13. Maryna Svintozelska, 14. Frączek Paulina, 15. Zabuzhko Yurii, 16. Miler Aleksandra, 17. Dorosz Małgorzata, 18. Chmielowiec Kacper, 19. Palak Angelika, 20. Tsybulchak Mykyta, 21. Przybyś Bartosz, 22. Tkaczyk Katarzyna, 23. Knap Karol, 24. Drobek Kasia, 25. Sterniewska Aleksandra, 26. Krupa Katarzyna.

2 Dom kultury w XXI wieku - wizje, niepokoje, rozważania, B. Jedlewska, B. Skrzypczak (red.), Centrum Edukacji i Inicjatyw Kulturalnych, Olsztyn 2009, s. 14.

3 M. Szmit, Rola uczelni wyższych w procesie rozwoju regionalnego: studium przypadku, [w:] Nierówności społeczne a wzrost gospodarczy. Modernizacja dla spójności społeczno-ekonomicznej, M. Woźniak (red.), Zeszyty Naukowe Uniwersytetu Rzeszowskiego, nr 18, UR, Rzeszów, s. 229.

4 Ibidem, s. 230.

5 Ibidem.

\section{BIBLIOGRAFIA}

Böhm A., O budowie i synergii wnętrz urbanistycznych, Wydawnictwo Politechniki Krakowskiej, Kraków 1981.

Dom kultury w XXI wieku - wizje, niepokoje, rozważania, B. Jedlewska, B. Skrzypczak (red.), Centrum Edukacji i Inicjatyw Kulturalnych, Olsztyn 2009.

Gehl J., Życie między budynkami. Użytkowanie przestrzeni publicznych, Wydawnictwo RAM, Kraków 2009.

Gehl J., Miasta dla ludzi, Wydawnictwo RAM, Kraków 2014.

Gzell S., Reurbanizacja: Uwarunkowania, Reurbanization: Preconditions, Urbanistyka, Międzyuczelniane Zeszyty Naukowe, Warszawa 2010.

Rykwert J., Pokusa miejsca. Przeszłość i przyszłość miast. (The Seduction of Place. The History and Future of the City), Międzynarodowe Centrum Kultury, Kraków 2013.

Studium uwarunkowań i kierunków zagospodarowania przestrzennego gminy Zaklików, Załącznik nr I do Uchwały XLI/197/02 Rady Gminy Zaklików z dnia 26 kwietnia 2002r. wraz ze zmianami wprowadzonymi: Uchwałą Nr XLI/235/2013 Rady Gminy Zaklików z dnia 20 września 2013 roku - I zmiana, Zaklików 2013 r. 
Szmit M., Rola uczelni wyższych w procesie rozwoju regionalnego: studium przypadku, [w:] Nierówności społeczne a wzrost gospodarczy. Modernizacja dla spójności społeczno-ekonomicznej, M. Woźniak (red.), Zeszyty Naukowe Uniwersytetu Rzeszowskiego, nr 18, UR, Rzeszów, s. 228-235.

Wrana J., Tożsamość miejsca. Kryterium w projektowaniu architektonicznym, Wydawnictwo Politechniki Lubelskiej, Lublin 2011.

Wrana J., Rola i znaczenie architektury w procesie scalania struktury przestrzennej miasta na przykładzie Lublina, Wydawnictwo Politechniki Lubelskiej, Lublin 2014.

Wrana J., Fitta-Spelina A. Rola architektury w integracji i estetyce miasta, [w:] Integracja sztuki i techniki w architekturze i urbanistyce, monografia, J. Flizikowski, G. Rzepecki (red.), Wydawnictwa Uczelniane Uniwersytetu Technologiczno-Przyrodniczego w Bydgoszczy, Bydgoszcz 2015, s. 407-415. 